\title{
PENGGUNAAN ALAT PELINDUNG DIRI SEBAGAI UPAYA DALAM \\ MEMUTUS RANTAI INFEKSI DI RUMAH SAKIT
}

\author{
Novi Pratiwi \\ novipratiwi211@gmail.com
}

\begin{abstract}
Abstrak
Rumah sakit adalah pemberi layanan kesehatan yang bermutu sesuai dengan standar yang sudah ditentukan salah satunya dengan melakukan upaya pencegahan dan pengendalian infeksi (PPI) dengan cara memutus rantai penularan infeksi. Upaya dalam memutus rantai infeksi di rumah sakit ini bisa dilakukan dengan menerapkan cuci tangan 6 langkah menggunakan sabun dan air bersih dengan benar dan menggunakan Alat Pelindung Diri (APD) dengan benar dan sesuai. Perawat termasuk dalam komponen rantai penularan infeksi. Seorang perawat yang dalam keadaan daya tahan tubuh menurun akan berpotensi terkena infeksi saat bekerja, sehingga perawat perlu melakukan cuci tangan dan menggunakan alat pelindung diri saat melakukan tindakan kepada pasien. Saran bagi perawat diharapkan lebih memperhatikan dan meningkatkan upaya dalam memutus rantai infeksi di rumah sakit untuk menjaga keselamatan pasien.
\end{abstract}

Kata kunci : Alat pelindung diri, upaya memutus rantai infeksi, perawat.

\section{Latar Belakang}

Rumah sakit adalah pemberi layanan kesehatan yang bermutu sesuai dengan standar yang sudah ditentukan salah satunya dengan melakukan upaya pencegahan dan pengendalian infeksi (PPI). Salah satu tantangan besar terhadap rumah sakit saat ini yaitu risiko terjadinya infeksi nosokomial (Hospital acquired infection) yang saat ini diganti dengan istilah baru yaitu "Healthcare Associated Infections" (HAIs) dengan pengertian yang lebih luas tidak hanya di rumah sakit tetapi juga di fasilitas pelayanan kesehatan lainnya. Juga tidak terbatas infeksi pada pasien saja, tetapi juga infeksi pada petugas kesehatan yang didapat pada saat melakukan tindakan perawatan pasien. Saat ini diperkirakan setiap harinya 1 dari 25 pasien rumah sakit menderita minimal 1 jenis HAIs (CDC, 2016).

Di rumah sakit banyak sekali jenis dan macam penyakit yang begitu kompleks. Dalam penanganannya banyak membutuhkan berbagai macam peralatan dan sejumlah orang petugas kesehatan yang berinteraksi secara langsung maupun tidak langsung dengan pasien yang dirawat di 
rumah sakit. Dengan begitu, risiko terjadinya infeksi nosokomial sangat besar. Infeksi nosokomial merupakan infeksi yang didapat dari pekerjaan yang merupakan masalah penting di seluruh dunia yang terus semakin meningkat.

Upaya pencegahan dan pengendalian infeksi dengan cara memutus rantai penularan infeksi merupakan cara yang paling mudah untuk mencegah penularan penyakit infeksi, tetapi hasilnya bergantung pada ketaatan petugas dalam melaksanakan prosedur yang telah ditetapkan. Upaya dalam memutus rantai infeksi di rumah sakit ini bisa dilakukan dengan menerapkan cuci tangan 6 langkah menggunakan sabun dan air bersih dengan benar dan menggunakan Alat Pelindung Diri (APD) dengan benar dan sesuai.

Komponen rantai penularan infeksi yaitu mulai dari agen infeksi, reservoir, pintu keluar, cara penularan, pintu masuk dan penjamu. Perawat termasuk dalam komponen rantai penularan infeksi dan dapat dimasukkan dalam pejamu rentan dan tempat tumbuhnya agen penyebab infeksi. Seorang perawat yang dalam keadaan daya tahan tubuh menurun akan berpotensi terkena infeksi saat bekerja, sehingga perawat perlu melakukan cuci tangan dan menggunakan alat pelindung diri saat melakukan tindakan kepada pasien.

Alat Pelindung Diri (APD) adalah kelengkapan yang wajib digunakan saat bekerja sesuai bahaya dan risiko kerja untuk menjaga keselamatan pekerja itu sendiri dan orang di sekelilingnya. Dalam kasus wabah penyakit menular, alat pelindung diri adalah kesiapan logistik yang krusial, layaknya obat-obat suportif (lifesaving), alat-alat kesehatan dan penunjang kesehatan lainnya.

Alat pelindung diri wajib tersedia untuk petugas kesehatan dalam menjalankan perawatan pasien. Bagi petugas kesehatan, penggunaan alat pelindung diri dibutuhkan untuk proteksi diri agar tenaga kesehatan tidak terjangkit penyakit. Hal ini patut diperhatikan karena selain kewajiban terhadap pasien, tenaga kesehatan memiliki tanggung jawab untuk menjaga kesehatan diri sendiri. Selain untuk proteksi diri, penggunaan APD yang sesuai untuk mencegah transmisi agen infeksius dari pasien ke orang lain.

\section{Metode}

Metode yang dilakukan dalam penulisan ini adalah metode kepustakaan yaitu dengan melakukan peninjauan dan mengumpulkan data-data yang diperoleh dari buku dan jurnal-jurnal terkini kemudian menganalisis data-data tersebut, mereview dan menentukan bahwa penggunaan Alat Pelindung Diri yang benar merupakan salah satu upaya dalam memutus rantai infeksi di rumah sakit. Pengolahan data dilakukan mulai dari 
menganalisis isi buku dan jurnal hingga kesimpulan dari penulis.

\section{Hasil}

Infeksi nosokomial atau infeksi yang berhubungan dengan pelayanan kesehatan atau Health Care Associated Infections (HCAIs) adalah penyakit infeksi yang pertama muncul dalam waktu antara 48 jam dan empat hari setelah pasien masuk rumah sakit atau tempat pelayanan kesehatan lainnya, atau dalam waktu 30 hari setelah pasien keluar dari rumah sakit. Dalam hal ini termasuk infeksi yang didapat dari rumah sakit tetapi muncul setelah pulang dan infeksi akibat kerja pada petugas di fasilitas pelayanan kesehatan.

Rumah Sakit dituntut untuk memberikan pelayanan yang bermutu, efektif dan efisien untuk menjamin Patient safety yang telah menjadi program pemerintah. Kementerian Kesehatan melakukan revitalisasi Program Pencegahan dan Pengendalian Infeksi (Program PPI) di Rumah Sakit yang merupakan salah satu pilar menuju Patient safety dengan harapan kejadian infeksi di Rumah Sakit dapat diminimalkan serendah mungkin. Studi dari tahun 1995-2008 menunjukkan prevalensi HCAIs di negara maju berkisar antara $5.1 \%$ dan $11.6 \%$. Di negara-negara Eropa dilaporkan rata-rata prevalensi HCAIs $7.1 \%$. Penelitian yang dilakukan di negara sedang berkembang menunjukkan tingkat infeksi di Rumah Sakit yang tinggi (5-19\%) dan rata-rata di atas $10 \%$.

Hasil penelitian di Polandia menurut (Deptula, 2015) diketahui bahwa infeksi kateterisasi vena sentral $30,2 \%$, intubasi $41,6 \%$ dan kateterisasi urin 17,5\%. Prevalensi tertinggi HAIs diamati antara pasien di unit perawatan intensif 39,8\% orang dewasa, pediatri 30,8\%. Di Indonesia sendiri, berdasakan hasil survey point prevalensi dari 11 Rumah Sakit di DKI Jakarta yang dilakukan oleh Perdalin Jaya dan Rumah Sakit Penyakit Infeksi Prof. Dr. Sulianti Saroso Jakarta pada tahun 2003 didapatkan angka infeksi nosokomial untuk Infeksi Luka Operasi (ILO) 18,9\%, Infeksi Saluran Kemih (ISK) 15,1\%, Infeksi Aliran Darah Primer (IADP) 26,4\%, Pneumonia 24,5\% dan Infeksi Saluran Napas lain 15,1\%, serta Infeksi lain 32,1\%. (Depkes, 2013).

Untuk mengatasi berbagai permasalahan infeksi tersebut, maka perawat dan tenaga kesehatan lainnya perlu untuk melakukan upaya dalam memutus rantai infeksi di rumah sakit. Salah satu upaya dalam memutus rantai infeksi tersebut adalah dengan menggunakan alat pelindung diri yang benar dan sesuai.

Berdasarkan data dari sebuah jurnal didapatkan data bahwa Alat Pelindung Diri (APD) yang biasa dipakai perawat yaitu jenis handscon/sarung tangan dan masker. 
Perawat memakai sarung tangan disesuaikan dengan tindakan yang akan dilakukan. Perawat memakai sarung tangan steril digunakan pada saat melakukan tindakan seperti perawatan luka, sedangan perawat memakai sarung tangan non steril dipakai apabila melakukan tindakan seperti injeksi dan tindakan pengukuran TTV.

WHO dan kementerian kesehatan sudah mengeluarkan pedoman mengenai penggunaan alat pelindung diri yang benar sesuai dengan faktor risiko, baik bagi para profesional kesehatan dan juga bagi khalayak awam. APD yang direkomendasikan oleh WHO dan Kementerian Kesehatan Republik Indonesia bagi petugas kesehatan contohnya saat menangani pasien COVID19 harus menggunakan APD level 3 antara lain pelindung mata atau pelindung wajah, penutup kepala, masker N95 atau yang setingkat, sarung tangan, gown all-cover atau apron, sarung tangan double sterile, dan sepatu boot.

\section{Pembahasan}

Perawat perlu memakai Alat Pelindung Diri (APD) disaat melakukan tindakan keperawatan sebagai salah satu upaya dalam memutus rantai infeksi guna menjaga keamanan perawat dan juga keselamatan pasien. Alat Pelindung Diri (APD) adalah suatu alat yang mempunyai kemampuan untuk melindungi seseorang yang fungsinya mengisolasi sebagian atau seluruh tubuh dari potensi bahaya di tempat kerja.

Alat pelindung diri merupakan salah satu peralatan yang digunakan oleh tenaga kesehatan untuk mencegah terjadinya infeksi nosokomial, melindungi penderita dari kemungkinan terjadinya infeksi dimulai dari pasien masuk, mendapatkan asuhan keperawatan dan tindakan medis sampai pasien pulang dari rumah sakit. Pemakaian alat pelindung diri dalam kegiatan sehari-hari lebih banyak berfungsi untuk pelindung pasien dibanding untuk pelindung perawat.

Tujuan penggunaan alat pelindung diri adalah untuk melindungi kulit dan selaput lendir perawat dari pajanan semua cairan tubuh dari kontak langsung dengan pasien. Alat pelindung diri meliputi sarung tangan, masker dan pelindung mata, topi, gaun dan apron. Salah satu alat pelindung diri yang digunakan untuk mencegah kontaminasi antara perawat dengan pasien saat melakukan tindakan adalah pemakaian sarung tangan dan masker.

Ada beberapa masalah yang sering dihadapi perawat dalam menggunakan alat pelindung diri (APD), yaitu:

1. Sering kali perawat tidak mengerti/sadar resiko yang akan terjadi jika tidak menggunakan alat pelindung diri

2. Perawat merasa panas jika menggunakan alat pelindung diri 
3. Perawat menggunakan alat pelindung diri yang tidak sesuai dengan ukurannya sehingga merasa sesak menjadikan tidak memakainya

4. Merasa merasa tidak nyaman atau tidak enak dipandang apabila memakai baju APD dengan ukuran yang besar yang tidak sesuai dengan ukuran baju

5. Bahan APD yang dipakai terlalu berat sehingga perawat tidak memakainya

6. Ketidakbiasaan pemakaian APD seperti sarung tangan, masker dapat mengganggu pekerjaan

7. Perawat yang tidak menggunakan alat pelindung diri tidak ada sanksi dari pimpinan yang berpengaruh pada ketidakpatuhan perawat dalam menggunakan alat pelindung diri

8. Tidak adanya contoh dari atasan untuk menggunakan alat pelindung diri yang membuat perawat mengikuti untuk tidak menggunakan alat pelindung diri.

Adapun pedoman umum penggunaan alat pelindung diri (APD) yaitu:

1) Selalu menjaga kebersihan tangan meskipun menggunakan APD

2) Segera melepas dan mengganti APD yang tidak dapat digunakan kembali setelah mengetahui APD tersebut tidak berfungsi secara optimal seperti sobek atau rusak

3) Segera mungkin melepaskan APD setelah selesai memberikan pelayanan kepada pasien dan hindari kontaminasi lingkungan diluar isolasi, para pasien atau pekerja lain, dan diri sendiri

4) Membuang semua perlengkapan APD yang tidak dapat digunakan lagi dengan hati-hati dan segera melakukan cuci tangan.

Adapun faktor-faktor penting yang harus diperhatikan dalam penggunaan alat pelindung diri (APD) yaitu:

1. Menggunakan APD sebelum kontak dengan pasien

2. Menggunakan APD dengan hati-hati, jangan menyebarkan kontaminasi

3. Melepas dan membuang APD yang tidak dapat digunakan lagi secara hatihati ke tempat limbah infeksius yang telah tersedia

4. Segera membersihkan tangan sesuai dengan langkah-langkah pada pedoman membersihkan tangan.

Jenis alat pelindung diri yang sering digunakan dalam tindakan keperawatan yaitu:

a) Sarung tangan

Sarung tangan merupakan penghalang (barrier) fisik paling penting untuk mencegah penyebaran infeksi, melindungi tangan dari bahan yang dapat menularkan penyakit dan melindungi pasien dari mikroorganisme yang berada ditangan petugas kesehatan. Sarung tangan harus diganti antara setiap kontak dengan satu pasien ke 
pasien lainnya, untuk menghindari kontaminasi silang.

Pemakaian sarung tangan sangat efektif untuk mencegah kontaminasi, tetapi pemakaian sarung tangan tidak menggantikan kebutuhan untuk mencuci tangan. Sebab sarung tangan bedah lateks dengan kualitas terbaikpun, mungkin mengalami kerusakan kecil yang tidak terlihat, sarung tangan mungkin robek pada saat digunakan atau tangan terkontaminasi pada saat melepas sarung tangan.

Dalam penggunaan sarung tangan perawat atau tenaga kesehatan lainnya perlu memperhatikan hal-hal sebagai berikut:

- Mencuci tangan dengan sabun sebelum dan sesudah menggunakan sarung tangan

- Mengganti sarung tangan jika berganti pasien atau jika sarung tangan sobek

- Segera mengganti sarung tangan setelah kontak dengan pasien atau setelah melakukan tindakan dan dibuang ditempat sampah

- Menggunakan sarung tangan hanya untuk satu tindakan saja

- Menghindari kontak dengan benda disekitar selain dalam tindakan
- Menghindari penggunaan atau mendaur ulang kembali sarung tangan sekali dipakai.

Pemakaian sarung tangan dilakukan saat ada kemungkinan kontak dengan darah atau cairan tubuh, sekresi, ekresi, membran mukosa atau kulit yang terlepas, saat akan melakukan prosedur medis yang bersifat invasive (misalnya pemasangan infuse, kateter), saat menangani bahan-bahan bekas pakai yang telah terkontaminasi atau menyentuh permukaan yang tercemar, serta memakai sarung tangan bersih atau tidak steril saat akan memasuki ruangan pasien yang telah dicurigai mengidap penyakit menular. Melepas sarung tangan sebelum meninggalkan ruangan dan segera melakukan cuci tangan untuk mencegah transfer mikroorganisme.

Pemakaian sarung tangan yang sama atau mencuci tangan yang masih bersarung tangan, ketika berpindah dari satu pasien ke pasien lain atau ketika melakukan perawatan dibagian tubuh yang kotor kemudian berpindah dibagian tubuh yang bersih, bukan merupakan praktik yang aman. Bakteri dalam jumlah bermakna pada tangan petugas yang hanya mencuci tangan dalam keadaan masih memakai sarung tangan dan tidak mengganti sarung tangan ketika berpindah dari satu pasien ke pasien lain. 
b) Masker

Masker harus cukup besar untuk menutupi hidung, mulut, dan bagian bawah dagu. Penggunaan masker bertujuan untuk menghindari cipratan sewaktu berbicara, batuk, atau bersin serta mencegah cairan atau percikan darah dan mikroorganisme memasuki hidung atau mulut petugas kesehatan. Perawat dianjurkan untuk menggunakan masker saat melakukan tindakan kesemua pasien terutama pada pasien dengan TB. Perawat yang menggunaan masker diharapkan mampu memberikan perlindungan terhadap transmisi infeksi melalui udara.

Masker terbuat dari berbagai bahan seperti katun ringan, kain kasa, kertas dan bahan sintetik lainnya yang tahan cairan. Masker yang terbuat dari katun atau kertas sangat nyaman tetapi tidak dapat menahan cairan atau efektif sebagai filter. Masker yang terbuat dari bahan sintetik dapat memberikan perlindungan dari tetesan partikel berukuran besar yang tersebar melalui batuk atau bersin ke orang yang berada di dekat pasien (kurang dari 1 meter).

Fungsi masker akan terganggu/tidak efektif apabila tidak dapat melekat pada wajah secara sempurna. Masker harus terpasang erat di wajah menutupi hidung dan mulut pemakai dan harus segera dibuang setelah dipakai. Bila masker tersebut basah atau kotor terkena sekret, masker tersebut harus segera diganti.

Dalam penggunaan masker perawat atau tenaga kesehatan lainnya perlu memperhatikan hal-hal sebagai berikut:

- Memasang masker sebelum memasang sarung tangan

- Tidak diperbolehkan/dianjurkan menyentuh masker ketika menggunakannya

- Melepas masker dilakukan setelah melepas sarung tangan dan cuci tangan

- Tidak membiarkan masker menggantung pada leher

- Segera melepas masker jika sudah tidak digunakan kembali

- Penggunaan masker sekali pakai sehingga tidak dianjurkan kembali menggunakan masker yang sudah dipakai.

\section{Penutup}

Kesimpulan dan Saran

Upaya dalam memutus rantai infeksi di rumah sakit bisa dilakukan dengan menerapkan cuci tangan 6 langkah menggunakan sabun dan air bersih dengan benar dan menggunakan Alat Pelindung Diri (APD) dengan benar dan sesuai guna menjaga keamanan perawat dan juga 
keselamatan pasien. Alat pelindung diri merupakan salah satu peralatan yang digunakan oleh tenaga kesehatan untuk mencegah terjadinya infeksi nosokomial, melindungi penderita dari kemungkinan terjadinya infeksi dimulai dari pasien masuk, mendapatkan asuhan keperawatan dan tindakan medis sampai pasien pulang dari rumah sakit. Alat pelindung diri meliputi sarung tangan, masker dan pelindung mata, topi, gaun dan apron. Saran bagi perawat diharapkan lebih memperhatikan dan meningkatkan upaya dalam memutus rantai infeksi di rumah sakit untuk menjaga keselamatan pasien.

\section{Daftar Pustaka}

Dewi, F., Handiyani, H., \& Kuntarti. (2016). Memutus rantai infeksi melalui fungsi pengorganisasian kepala ruang rawat. Jurnal Keperawatan Indonesia, 19(2), 107-115.

Herman, M. J. \& Handayani, R. S. (2016). Sarana dan prasarana Rumah Sakit Pemerintah dalam upaya pencegahan dan pengendalian infeksi di Indonesia. Jurnal Kefarmasian Indonesia, 6(2), 137-146.

Husein, B., Sidipratomo, P., Meilia, P. D. I., \& Christianto, G. M. (2020). Tinjauan etik prioritas Alat Pelindung Diri (APD) untuk Profesional Pemberi Asuhan (PPA) kedokteran dan kesehatan. JEKI, 4(2), 47-51.
Hutahaean, S. \& Handiyani, H. (2018). Pengembangan fungsi dan peran kepala ruangan dalam pencegahan dan pengendalian infeksi di RS X. Jurnal Akademi Keperawatan Husada Karya Jaya, 4(1), 53-64.

Kemenkes RI. (2015). Pedoman nasional keselamatan pasien rumah sakit (Edisi III). Jakarta.

Molina, V. F. (2012). Analisis pelaksanaan program pencegahan dan pengendalian infeksi nosokomial di Rumkital Dr. Mintohardjo. Jakarta: FKM UI.

Nugraheni, R., dkk. (2012). Media kesehatan masyarakat indonesia. Jakarta: Salemba Medika.

Permenkes RI. (2017). Pedoman pencegahan dan pengendalian infeksi di fasilitas pelayanan kesehatan no 27. Jakarta: Permenkes RI.

Rotti, G. \& Sjattar, E. (2014). Hubungan fungsi manajemen kepala ruangan dengan pelaksanaan pencegahan dan pengendalian infeksi di ruang rawat inap Rumah Sakit Umum Pusat Prof R. D Kandou Manado, 4 (1), 69-77.

Septiari, B. B. (2012). Infeksi nosokomial. Yogyakarta: Nuha Medika.

Simamora, R. H. (2020). Learning of Patient Identification in Patient Safety Programs Through Clinical Preceptor Models. Medico Legal Update, 20(3), 553-556. 
Simamora, R. H. (2019). Pengaruh Penyuluhan Identifikasi Pasien dengan Menggunakan Media Audiovisual terhadap Pengetahuan Pasien Rawat Inap. Jurnal Keperawatan Silampari, 3(1), 342-351.

Sofia, S., Saragih, G. N., Rahayu, B. M. S., \& Alvionia, D. W. (2014). Ruangan dengan kepatuhan perawat dalam penerapan pengendalian infeksi nosokomial di Rumah Sakit Santo Yusup Bandung. Jurnal Keperawatan Indonesia, , 69-78. 